\title{
Hydronyms in Ocna Șugatag commune, Maramureș county
}

\author{
Adelina Emilia Mihali* \\ "Sextil Puşcariu" Institute of Linguistics and Literary History, Str. Emil Racoviță 21, 400165, Cluj-Napoca, Romania
}

\section{Article info}

History:

Received July 6, 2018

Accepted July 26, 2018

Published October 7, 2018

Key words:

toponym

hydronym

anthroponym

surname

toponymic pattern

\begin{abstract}
The article is an analysis of hydronyms from Ocna Șugatag, Maramureș county and it represents a part of a larger research on Maramuseș toponymy. Settled on a hilly area, at the foot of Gutii mountains, on Mara river, the boundaries of the four localities belonging to the commune: Breb, Hoteni, Sat-Șugatag and Ocna Șugatag are characterized by a vast hydronymic net, with valleys and springs, affluents of Mara river, but also wells, lakes and swamps. The corpus of the work has been extracted from inedit toponymic material collected during field researches. The topic names are individually discussed, for each hydronym the answers given by the subject have been indicated, and also different forms, when registered, and supplementary data known to us, as Ocna Şugatag is our native place. The purpose of the study is to establish the etymology of hydronyms in the researched area. In order to provide a broad perspective on the hydronymy and the anthroponymy which represents its basis, we also indicate the distribution of topic names in Transylvania and the frequency of surnames in the county. After the analysis of toponyms referring to waters, they are classified from the structural point of view in order to illustrate the identified syntactical and morphological patterns. Our conclusion is that the hydronyms in Ocna S,ugatag, Maramureș county reflect property relationships and geomorphological and geological features of the area.
\end{abstract}

\section{Introduction}

Having a greater stability than appelatives or anthroponyms, the toponyms, especially hydronyms "se păstrează deseori cu o mare tenacitate, chiar și la schimbarea populației” [preserve themselves, sometimes tenaciously, even during population shifts] (Frățilă, 2002, p. 72). Thus, the name of waters or mountains are considered to be prior to other topic names, but there are situations when this principle does not function, especially for water names based on an anthroponym (Bolocan, 1975, p. 383).

The study's purpose is to analyse the toponyms which denominate waters (rivers, valleys, springs, lakes, swamps) in our native commune, Ocna S,ugatag, Maramureș county. The corpus the work is based upon has been extracted from the toponymic material collected during direct field research ${ }^{1}$, not published by now, and it represents a part of a larger research on Maramuseș toponymy. The topic names have been literarized, the phonetic transcription is used only for obvious phonetic specific features in the local speech.

Ocna Șugatag commune is placed in Maramureșului Depression, on the interfluve between Mara and Cosău rivers, at the eastern foot of Gutîi Mountains, in the northern part of Maramureș county. It administrates the following localities: Ocna Șugatag (centre of the commune), Breb, Hoteni and SatȘugatag. The first documentary attestation of Ocna S, ugatag dates back in 1355 as fodine salium, referring to a way used for carrying salt towards Austria, passing by Giulești village. Other names the locality has

\footnotetext{
*Email address: adelinatatar@yahoo.com.

${ }^{1}$ The inquiries were done during the summer of 2017, under the surveillance of Dumitru Loșonţi, CS I PhD at the "Sextil Pușcariu” Institute of Linguistics and Literary History from Cluj-Napoca. Here is the list of the subjects whose answers we have used: I. Birtoc Petru, 64 years old, farmer, Sat-Șugatag; II. Hotea Ioan, 53 years old, duty person, Hoteni; III. Chira Ana, 50 years old, housewife, Hoteni; IV. Borca Ioan, 71 years old, miner, Breb; V. Tătar Gheorghe, 57 years old, miner, Ocna Șugatag.
} 
Adelina Emilia Mihali

been referred to in documents along the time are: Zalatnya Sugatag 1360; Sugatag 1419; Akna Sugatag 1828. For a year (1991-1992), the commune's name was Ocna Maramureșului, then it returned to its previous name, Ocna S,ugatag ${ }^{2}$.

The locality Sat-Sugatag (Zalatyna, villa olachalis Sugatag-falva, Swgathakfalwa) was attested in 1360; its previous names (Sugatagh 1365, Sugathagh 1459, utraque Swgathak 1472 - for Sat-S,ugatag and Ocna S,ugatag, Sugatagh 1828, Sugatag 1851) reflect the connection to the salt mine in Ocna S,ugatag. The determiner S,ugatag has been differently interpreted: Ștef (2016, p. 159) supports Papahagi's opinion (1981, p. 156, see the notes), according to which the topic name comes from the Hung. sóvago 'salt cutter' + Germ. Tage 'day worker', especially because Sat-Șugatag "e considerat ca fiind locuit de oameni lucrători cu ziua, care nu sînt «ńemńeșin»" [is considered to be the village whose inhabitants are day workers, who are not «ńemńeși » 'land owners'] Kiss (1988, p. 64, s.v. Akna Sugatag) considers the toponym deriving from the verb sugg 'to whisper' and suff. -atag, We agree with Kiss's opinion.

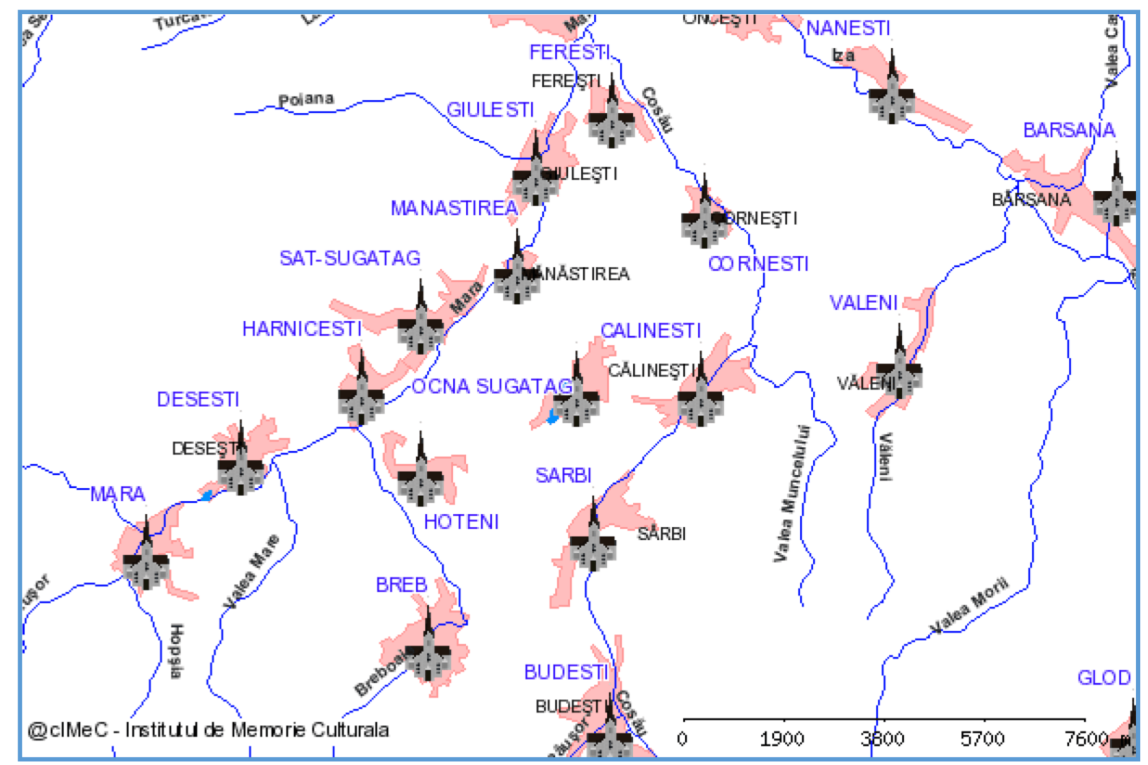

Hoteni locality, attested in 1360 (Zalatina), together with Breb (Hódpatakfalwa, villa olachalis Hatpatokfalva), is historically mentioned only in 1555 as Hotynfalwa. The oiconym Hoteni comes from the group name hoteni < surname Hotea + suff. - eni. The name Bréb has been registered in documents beginning with 1715 and it is based on the appellative breb 'beaver'.

\section{Topic names denominating waters}

As the researched area is placed in a hilly landscape, there are a lot of smaller or larger affluents of Mara river, springs and lakes. Their names indicate property relationships or features of the water. Semantically, the hydronyms in Ocna Șugatag can be placed into 4 classes: 1. river names, 2. valley names, 3. small springs and wells names and 4. stagnant water names.

\subsection{Topic names denominating rivers}

MÁRA (H, S), left affluent of Iza, of $40 \mathrm{~km}$ in length, referred to, in Hoteni, with the general term Rîu 'River'. The etymology of the name has been intensely debated, but the most appropriate seems to start from the stem mar - 'water' ( $+-a$ "considered a feminine definite article or a "toponymic suffix"), cf. Sanscr. mara, Celtic mor, Gothic marei, Latin mare, Slavic mare, Lithuanian mares (Xenopol, 1985, p. 5051), probably the basis of Mureş hydronym, too.

\footnotetext{
${ }^{2}$ The previous names of the localities subjected to inquiry were listed according to Suciu (1967 and 1968).
} 
RÎ́U BRÁZILOR (S), denomination for the superior flow of Mara river; it springs from under Pleşca peak, "it springs from Braz, from the pastures" I, and it consists of three smaller streams Valea Răchiţii, Valea Seacă and Valea Podului, passes through Cheile Tătarului, collecting the other valleys from the mountain Vidrişca, Tălhăraşu, Valea Roşie and Valea Șteviei. - From rîu + top. n. Brazi < brad (pl. brazi).

\subsection{Topic names denominatig valleys}

BĂRCOȚEÁSCA (S). - From adj. that became a noun bărcoțeasca < p.n. Bărcotă (see Dor, p. 199) + suf. -easca. In Borşa, MM, there is a byname Bîrcotă, also registered in toponymy (see Mihali, 2015, p. 137, 161).

BREBOÁIA (B), affluent of Marei, "it springs from Măgură" IV. - From byn. Breboaia < p.n. Breb, 5 times mentioned as a surname in the county ${ }^{3}$, or from breboaia 'breb's female'.

BREBOÍŢA (B) IV. - From top. n. Breboaia + dim. suff. -ița.

CÎRSTOÁIA (S), "a small valley, it flows into the river [Mara]" I. - From byn. Cîrstoaia < p.n. Cîrstea + suff. -oaia.

CîCÁCEA (S), another denomination for Cîrstoaia, I. - From n.n. Cîcacea. Cf. top. n. Căcîcea (Vişovan, 2005, p. 31; TTRT-Valea Hășdății, p. 35).

COPĂCíȘ (B), “dale” IV. - From top. n. Copăciş, hay field < copăciş 'place with many trees' < copac + coll. suff. $-i s ̧$.

DĂRÁSCA (B, H, O, S), "valley that flows from Hoteni” I, “valley” III, V. - From p.n. Dărasca $a^{4}$ < p.n. Daru (Iordan, 1983, p. 166; Dor, p. 102, p.n. Mardarie, p. 257, p.n. Dar, and the forms Dărescu, Dărești, Dărăști, Dărăscu) + suff. -(e)asca.

RUGINOÁSA [ruğînósa] (B), "small dale” IV. - From adj. ruginos, -oasă '(about a place) with rustcoloured water'. The hydronym is also spread in other areas of Transylvania (Vișovan, 2005, p. 311; TTRTSălaj, p. 282; TTRT-Valea Hășdății, p. 101).

SĂRÁTA (O), V. - From adj. sărat, - $\breve{a}$, which became a noun 'salty, rich in salt'. Even though the valley has drinking water, it flows through and collects water from an area rich in salt. The topic name is registered in Maramureș in other places known for salt deposits (see Vişovan, 2005, p. 315).

SUNĂTOÁREA (B), “valley at the entrance of the village” IV. - From adj. sunător, -oare, which became a noun 'makes or propagates sounds'. The name is usually given to running waters which form waterfalls on their flow (see Iordan, 1963, p. 58). In Maramureș, the topic name is also registered in Strîmtura locality (Vişovan, 2005, p. 334).

TĂLHĂRÁȘU (S), “it springs from Pleșca forest, comes through Cheile Tătarului and flows into Valea Roșie” I. - From tălhăraș < tălhar, var. of tîlhar 'thief, robber' or n.n. Tălhăraș < tălhar 'scoundrel; wicked, infamous person' + suff. -aș. Cf. top. n. Tălhăroaia (Vișovan, 2008, p. 243).

TÎ́LBUREA [tílburena] (B, S), “a small valley” I, "water” IV. - From adj. that became a noun tîlbure, var. of tulbure '(about waters) restless, whirling.' The toponym is widely spread in Maramureș (Vișovan, 2005, p. 344; 2008, p. 245).

VÁLEA BORCÚTULUI (B), “it goes up to Budești” IV. - From vale + top. n. Borcut (see infra). VÁLEA CÁSELOR (B), "valley at the entrance of the village, it flows into Breboaia” IV. - From casă (pl. case).

VÁLEA CHÉII (S), "it comes down from Iezăr", "Valea Iezărului and Valea Horjii make together Valea Cheii after they pass through Cheie" I. - From top. n. Cheia < cheie "valley that meanders between two rock walls and opens passage towards a field or a place between two provinces; gorge" (MDA).

\footnotetext{
${ }^{3}$ The frequency of surnames in the county is given according to DFNFM.

${ }^{4}$ The anthroponym Dărasca is mentioned in the birth register from Breb locality beginning with 1923.
} 
VÁLEA HÓRJII (S), “it springs from a móciră from under Vîrvu lu Ștefan; swampy water” I. - From top. n. Horja < from surname Horja, for 34 people in the county.

VÁLEA IÉZERULUI (S), “it comes from Iezăr”. - From top. n. Iezer < iezer 'mountain lake'.

VÁLEA LU TODORÚT, (S), “it springs from Piatra Mică, it flows towards Giulești” I. - From hyp. Todoruţ < p.n. Todor, var. of Teodor. The surname Todoruț is given to 30 people in Maramureș.

VÁLEA MÁNDRULUI (S), "it comes from under Preluca Iurii and it flows into Valea Podului" I. - From surname Mandru (see Iordan, 1983, p. 289). Cf. fam. n. Mandra, frequent in the locality, having 112 occurrences in Maramureș.

VÁLEA MÁRE (B, H), "valley directing towards Mara, it flows into Mara" II, "it comes from Gutin, it flows into the river in Desești" III, "water from under Gutin” IV. - From adj. mare.

VÁLEA MISÁRĂȘULUI (S). - From p.n. Misarăș. The surname Misarăşs is registered once, Misaraş two times, Misaroş - 26 times, but Mesaroș has 270 occurrences, being very frequent in Sat Șugatag.

VÁLEA NICHITÉȘTIULUI [ ńit'it’esșt’ului] (B) IV. - From top. n. Nichitești < group n. nichiteşti $<$ byn. Nichita, nowadays registered in the locality. As a surname, Nichita has a frequency of 143 in the county.

VÁleA PÓDULUI (S), I. - From top. n. *Pod < pod 'plateau, terrace' (Iordan, 1963, p. 33).

VÁLEA PÓPII (H), "small valley” II. - From popă 'priest'.

VÁLEA RĂCHÍȚII (S), “it comes from Răchita in Giulești”. - From top. n. Răchita < răchită 'willow'.

VÁLEA RÓȘIE (S), "it springs from the forest, from under”. - From adj. roşu, -ie.

VÁLEA SEACĂ (S), I. - From adj. sec, seacă 'which has no (more) water, wherefrom water has (definitively or temporarily) disappeared'.

VÁLEA ȘTÉVII [válę ștéd’i] (S), “it comes from Ștevea” I. - From top. n. Ștévea < from șteve, var. of ștevie 'name for a series of herbaceous plants' (DLR).

VĂLCEÁUA CĂȚÉLII [vălč̌́úua cățélii] (H), II, “when it rains, there forms a dale” IV. - From vălcea, var. of vîlcea 'small rivulet' + cățea 'bitch'.

VĂLCEÁUA CRÁMELOR (B), "in Crame, it flows into Valea Mare” IV. - From top. n. Crame < cram (pl. crame), var. of crámă 'hut, outhouses, annexes around the house' (see also TTRT-Sălaj, p. 89).

VĂSCOÁIA (S), "small valley that flows into Valea Răchițiii; it springs from Între Rude, from under Su Vîrv" I. - From byn. Văscoaia < p.n. Vasc(u), not registered in the locality nowadays, but it is present in Maramureș: Vasc -57 people, Vascu - 5, Vascul - 101, Vasko - 8.

VÎLCEÁ (B), "it flows into Breboaia” IV. - From vîlcea.

VIDRÍȘCA (S), "it springs from Pleșca forest, it goes through Cheile Tătarului and it flows into Valea Roșie” I. - possibly from hyp. Vidrişca < p.n. Vidra (DoR, p. 405; Oancă, 2016, p. 130) + suff. -işcă (see Pascu, 1916, p. 249-250) or from Sl. vydriška.

\subsection{Topic names denominating wells and springs}

BORCÚT (B), "mineral water spring” IV. - From borcut 'mineral water'. The topic name is quite spread in the county (see Mihali, 2015, p. 60; Vişovan, 2005, p. 24; 2008, p. 21).

CIURGẮU (O), V. - From ciurgău 'drain or pipe for the spring water冈. For this toponym area see also TTRT-Valea Hășdăţii, p. 39; TTRT-Valea Ierii, p. 41; TTRT-Sălaj, p. 73; Vişovan (2005, p. 36; 2008, p. 34).

CIURÓI (H), "spring” II. - From ciuroi 'spring that flows through a narrow drain made of bark; chute, small gutter, etc.' (DLR). See also Mihali (2015, p. 107); Vişovan (2008, p. 37, p. 34); TTRT-Sălaj, p. 70.

FîNTÎNA CIÓTULUI (S), I. - From fîntînă "spring” + byn. Ciotu. 
FÎNTÎNA CU SOLOMÎ́ZDRĂ (O), V. - From reg. solomîzdră, var. of salamandră 'species of tailed amphibian, resembling the lizard, with short sideways directed legs, with a wide flat body, having black with yellow spots skin, a shiny tegument which secretes an irritant substance having a protective role' (DLR).

FÎNTÎNA DE SLÁTINĂ (O), small lake with salty water, displayed as a well, supplied by a saline spring, a place where the locals take saline water from, "a well with saline water" V. - From prep. de + noun slatină 'salty, saline water".

FîNTÎNA DE LA DîMBURÉLE (B). IV. - From prep. de la + top. n. Dîmburéle < dîmburel (pl. dimburele).

FÎNTÎNA HÚCIULUI (B), "well at the roots of an alder tree, at the entrance of Huciu Des" IV. - From top. n. Huciu [Des] < buci 'thicket'.

FîNTÎNA IÉDULUI (S), spring, "people say that there, near a stone, they heard the deer kid bleating” I. - From ied 'male kid of deer'. Cf. anthrop. Iedu.

FÎNTÎ́NA LU CÎRNÁT, (S), I. - From n.n. Cîrnaț, also a byname in Hoteni.

FÎNTÎ́NA LU DRÎ́DU (S), I. - From n.n. Drîdu.

FÎNTÎNA LU GÁBOR (H), “well” II. - From Hung p.n. Gabor 'Gabriel', past and present first name in the area. The surname Gabor has 120 registrations in the county.

FÎNTÎNA LU HÁȘTOR (S), "strong spring, between Laz and Văratec” I. - From p.n. Hastor, possibly a Jewish name.

FîNTÎ́NA LU PĂPÚC (S), I. - From byn. Păpuc. The surname Papuc is registered for 9 people in Maramureș.

FÎNTÎ́NA LU ȘTEȚ (S), “it is under Cheie, under Piatra Mare” I. - surname Șteț, frequent in SatŞugatag, for 167 people in Maramureș.

FîNTÎNA LU TÓDOR (S), "it is in Horja, good water" I. - From p.n. Todor, var. of Teodor. The surname Todor is registered in Maramureș for 51 people.

FÎNTÎ́NA LU VASALÍ-A MOÁȘII [fîntî́na lu vasalíi-a mọşî] (S), “it is under Piatra Mare” I. - From first name. Vasalie, var. of Vasile + byn. A Moaşii.

FîNTÎ́NA MÁNCIULUI (S) I. - From surname Manciu, for 52 people Maramureș. Nowadays, the surname is not known in the locality.

FîNTÎNA MẮGURII (B), “spring on Măgura” IV. - From top. n. Măgura < măgură 'tall, round, smooth hill'.

FÎNTÎ́NA PRÉLUCILOR (S), “water with lăturiș" I. - From top. n. Préluci < prelúcă (pl. preluci) 'small glade' (DLR).

ŞTIUBÉI (H), “well” III. - From știubei 'well having a shallow spring with a știubei as a casting (3); generalizing, shallow well; spring of a running water' (DLR). The toponym is spread in other areas of Transylvania, too (TTRT-Sălaj, p. 305; TTRT-Valea Ierii, p. 163; TTRT-Valea Hășdății, p. 107).

\subsection{Topic names denominating stagnant waters}

BÁLTĂ (B, H), "people used to ret hemp in it, it is situated between Hoteni and Breb” IV. - From baltă '(larger) area of stagnant water, geologically natural, shallow, with specific aquatic vegetation and fauna' (MDA).

\footnotetext{
${ }^{5}$ For lăturiş, subject I offered the following explanation: "it is a worm, it has many legs and a wide body and when it goes it straightens its body; it lives in rocky areas, where the springs are rockiest, sandy, in cold mountain waters", "the water with lăturiș is good for drinking". The meaning of lăturiş mentioned by our subject is not registered by the dictionaries, but MDA registered the word lătunoi, var. of lătunoaie '(reg.) species of insect which lives at the bottom of the waters (Gumarus Pulex)'. Our colleague, Veronica Ana Vlasin, confirmed the presence of the word lătunoi, having the meaning our subject specified for lăturiș, in Cozla locality, Sălaj county.
} 
GÁBORI (O), lake with fresh water, resulted from salt mine crumbling, "large puddle" V. - From Hung. Gábori < p.n. Hung. Gabor. The lake keeps the latest name of the salt mine.

IÉZER (S), I. - From iezer 'mountain lake' (see also Mihali, 2015, p. 97; Vișovan, 2005, p. 149; 2008, p. 121).

LÁCU RÓȘU (O), lake with saline water, named like that because of the copper-coloured water, V. From lac + adj. roşu.

LÁCU VRĂJITOÁREI (O), lake with saline water, V. - From vrăjitoare 'witch'. The toponym is due to the wild appearance of the lake. The slopes towards the hole are steep and covered in rich vegetation (trees, elder bushes, hazelnut trees, nettles, etc.), which make the thickets impenetrable, especially in summer. Moreover, the surface of the lake is covered by duckweed, giving the lake a wild, witchy appearance, inspiring fear to the one who goes towards it for the first time.

MÓCIRA (H, S), "large swamp" I, "it is swampy" II, "swampy land” III. - From mociră 'watery, swampy, muddy place; marsh'.

MÓCIRA ÁLBULUI (B), “swampy land” IV. - From p.n. Albu. The surname Albu is registered for 186 people in Maramureș.

MÓCIRA CU LÚȘTELE (S), "many luște [a flower] grow there in spring” I. - From prep. cu + luşte 'name for two herbaceous plants from the Liliacee family, with straight leaves, with big greenish outside and white inside flowers, disposed in a dense raceme' (DLR).

MÓCIRA DIN LAZ (S), I. - From prep. din + top. n. Laz<laz 'land resulted after cutting down a forest'.

MÓCIRA MÁRE (S), part of the pasture, "buffalos use to bathe in mociră" I. - From adj. mare.

ÓREGHI [óreǵi] (O), lake with saline water, resulted after a salt mine crumbling, "saline puddle” V. From Hung. surname Oreg, attested beginning with 1554 < Hung. öreg "old" (Kázmér, 1993) or directly from the Hung. öreg 'old'. In geological studies or in touristic reviews, the Romanian name Lacul Bătrîn also appears, as it is the oldest bathing place in the locality. The local people, no matter their ethnic belonging, use the name Oreghi.

TĂU (H), "the puddles in Hoteni; people used to ret hemp there" II, "Hoteni people's puddle" III. From tău 'mountain lake'. See Baltă.

TẮU CHENDROÁII (B), TẮU CRENDOÁIII, "puddle with moss under Piatra Mare” IV. - From byn. Chendroaia < p.n. Chendre(a) or Chender (Iordan, 1983, p. 112) + suff. -oaia. In Maramureș, the surname Chender has a frequency of 7, Chendre (a) is not registered in DFNFM, but there is a Chendrean for 7 people. The form Tău Crendoaiei given by our subject is a variant with metathesis.

TẮU CRĂCIÚNII (B), IV. - From p.n. Crăciuna (see DoR, p. 36). Crăciuna is not registered as a surname in Maramureș, according to DFNFM, but the surname Crăciun has a frequency of 607 in the county.

TẮU MORĂRÉNILOR(B), IV. - From the group name Morăreni < p.n. Morar + suff. - eni. P.n. Morar is a surname with the frequency of 777 in Maramures, and also a byname.

TĂU SĂRÁT (B), IV. - From adj. sărat "with salty water”.

TẮUL FẮRĂ FUND $(\mathrm{O}), \mathrm{V}$. - From prep. fară + fund 'down; bottom limit'. The lake has this name because, as it is the deepest lake in Ocna Şugatag $(32.9 \mathrm{~m})$, and the previous tries of measuring its depth using rudimentary means had been useless. The local people also explain the name referring to a legend about a man who drowned there, together with his cart drawn by buffaloes. As nothing of their remains has ever returned to the surface again, "that means the lake is bottomless". 


\section{Linguistic appreciations}

In the area subjected to our study, the hydronym Mara, based on an Indo-European stem, belongs to the oldest toponymic layer. The majority of the toponyms are Romanian, except the two saline lakes resulted from salt mines crumbling, Gabori and Oreghi, the Hungarian Genitive forms of person names. The linguistic contact and the influence of Hungarian is phonetically identifiable due to the place of the stress on the first syllable in toponyms like Mócira and Préluci (Fîntîna Prélucilor).

From the structure point of view, the topic names denominating waters in Ocna S, ugatag, Maramureș county reflect patterns or toponymic types emphasizing the contribution of different parts of speech to the toponymic inventory as well as the frequency of some syntactic structures. Thus, the simple topic names are based on:

- nouns in the singular: Baltă, Borcut, Ciurgău, Ciuroi, Iezer, Móciră, Știubei, Tău, Tălhăraș, Vîlcea;

- adjectives indicating a feature of the water: Ruginoasa, Sărata, Sunătoarea, Tillburea. The adjectives initially functioned as determiners of a noun (e.g. Valea Sărată), then, themselves became nouns by taking up the definite article;

- derivates with collective suffix -iş: Copăciş, or the diminutival suffix -iță from another topic name: Breboiț, the latter indicating a size relationship between two water courses close to each other. Some hydronyms come from feminine person names created from masculine anthroponyms using the suffix -oaia (Cîrstoaia, Văscoaia) or the suff. - easca (Dărasca), or they are based on a nickname (Cîcacea).

But most of the topic names are compounds of lexical elements having a unitary meaning and a common denominative function. The best represented typological pattern is the one with a Genitive determiner, indicating possession or affiliation to a region. Thus, the determiner can be an appellative, anthroponym or another toponym. In the denominative structures Fîntîna Iedului, Lacu Vrăjitoarii, Valea Caselor, Valea Cățelii, Valea Popii, the determiner, a common noun in the Genitive, refers either to possession (Valea Popii), or to something out of ordinary in the local fauna (Valea Iedului) or a specific feature of the area the geographical object is placed in (Valea Caselor).

Most of the Genitive topic structures have an anthroponymic determiner - a surname (Fintîna lu Șteț, Fîntîna Manciului, Valea Mandrului), byname (Fîntîna Ciotului, Fîntîna lu Cîrnaț, Fîntîna lu Păpuc), personal nickname (Fîntîna lu Drîdu), feminine anthroponym (Tău Chendroaii), group name (Tău Morărenilor), first name + byname (Fîntîna lu Vasali-a Moașii). In some situations, it is difficult to establish if the toponym is based on a surname, a first name, or a byname as the anthroponym circulates in all the three forms (Fîntîna lu Gabor, Fîntîna lu Todor, Mócira Albului, Valea lu Todoruț, Valea Misárășului) or it is both first name and also a byname (Tău Crăciunii). The anthroponymic determiner has either an enclitic masculine or feminine article (Fîntîna Ciotului, Mocira Albului, Tău Crăciunii, Valea Mandrului, Valea Misarășului) or a proclitic one (Fîntîna lu Haştor, Fîntîna lu Gabor).

The third subclass of the typological pattern noun + noun in the Genitive contains topic names which have a toponymic determiner in their structure. In this situation, the Genitive indicates the placement, the geographical object being a part of a larger area (Fîntîna Huciului, Fîntîna Măgurii, Fîntîna Prelucilor, Valea Cramelor, Valea Cheii, Valea Horjii, Valea Nichiteștiului) or its source (Valea Iezerului, Valea Răchiții, Valea Stevii).

Another typological pattern in the hydronymy of the area is noun + preposition + noun, either an appellative (Fîntîna cu Solomîzdră, Fîntîna de Slatină, Mócira cu Luștele, Tău färă Fund), or a topic name (Fîntîna de la Dimburele, Mócira din Laz). The prepositions cu, de, fără indicate, in this context, a feature of the water or of the place and din and de la refer to the geographical position of the water in relation with another bigger or better known geographical object.

The hydronyms following the pattern noun + adjective are not very many, but they are an important reference point in establishing the specific features of soil and water. The adjectival determiner offers information about the water colour (Lacu Roșu, Valea Roșie), water quality (Tău Sărat, Valea Seacă) or size 
(Mócira Mare, Valea Mare). The determiner roșu denominates springs that pass through areas rich in iron (see also Ruginoasa) or having a greater concentration of salt, which makes the water copper-coloured.

The analysed hydronyms illustrate the fact that the toponyms, as elements of the vocabulary, are subjected to the same word formation means as the common nouns, valorising all the structures of the language.

\section{Conclusions}

Our research underlined the fact that the hydronyms in Ocna S,ugatag, Maramureș county reflect, on the one hand, the interdependence between toponymy and common vocabulary, and, on the other hand, between toponymy and anthroponymy. When talking about wells and springs in the mountain area, the property relationships are tighter than for water courses accessible to an entire community or even to more collectivities. Thus, the small springs, often placed in a hay field area usually belonging to a family, are called after their owner even if they are used by all the members of the community. This denomination possibility preserves anthroponyms which disappeared long ago, as their bearers moved away (Drîdu, Haştor, Văscoaia), or we can identify frequent surnames, old bynames, personal nicknames or first names. From this point of view, the hydronymy and toponymy, in general, represent important parts of the Romanian anthroponymy, both synchronic and diachronic, that is why their indexing and research become a sine-qua-non condition for ethnic identity awareness and the evolution of human settlements.

\section{Bibliography}

Bolocan, Gh. (1975). Stratificări în toponimie [Stratifications in toponymy], in “Limba Română, vol. XXIV, nr. 6, p. 383-385. DFNFM = Vişovan, Ș., Farcaș, M., Frînc, M.S., Vișovan, S.S., Vişovan, M. \& Farcaș, S. (2007). Dicționar de frecvență a numelor de familie din Maramureş [Dictionary of frequency for surnames in Maramureș], Editura Universității de Nord, Baia Mare. $\mathrm{DLR}=$ Dicționarul limbii române [Dictionary of Romanian Language], new series, Bucharest, 1965 sqq.

DOR = Constantinescu, N.A. (1963). Dicționar onomastic românesc [Romanian Onomastics Dictionary], Editura Academiei Republicii Populare Române, București.

DTRO = Dicționarul toponimic al României. Oltenia [Toponymic Dictionary of Romania. Oltenia], I, coordinated by prof. univ. dr. Gh. Bolocan, with an Introduction by Gh. Bolocan, Editura Universitaria, Craiova, 1993.

Frățilă, V. (2002). Studii de toponimie și dialectologie [Studies on toponymy and anthroponymy], Editura Excelsior Art, Timișoara.

Iordan, I. (1963). Toponimia românească [Romanian toponymy], Editura Academiei Republicii Populare Române, București.

Iordan, I. (1983). Dicționar al numelor de familie românești [Dictionary of Romanian surnames], Editura Științifică și Enciclopedică, București.

Kázmér, M. (1993). Régi magyar családnevek szótára XIV-XVII. század, Magyar Nyelvtudományi Társaság, Budapest.

Kiss, L. (1988). Földrajzi nevek etimológiai szótára, negedik, bövitett és javitott kiadás, I, II, Akadémiai Kiadó, Budapest.

MDA = Micul dicționar academic, vol. I-IV, Academia Română, Institutul de Lingvistică „Iorgu Iordan - Al. Rosetti”, Editura Univers Enciclopedic, București, 2002 și urm.

Mihali, A.E. (2015). Toponimie maramureșeană. Valea superioară a Vișeului [Maramureș toponymy. Superior valley of Vișeu], Editura Mega, Cluj-Napoca.

Oancă, T. (2016). Microsisteme antroponimice românești [Romanian anthroponymic microsystems], Editura Grafix, Craiova.

Papahagi, T. (1981). Graiul și folklorul Maramureșului, $2^{\text {nd }}$ edition, in Grai, folklor, etnografie, edition and preface by Valeriu Rusu, Editura Minerva, București.

Pascu, G. (1916). Sufixele românești [Romanian suffixes], Librăriile Socec \& Co., C. Sfetea, Pavel Suru, București.

Suciu, C. (1967). Dicționar istoric al localităților din Transilvania [Historical dictionary of localities in Transylvania], Editura Academiei Republicii Socialiste România, vol. I.

Suciu, C. (1968). Dicționar istoric al localităților din Transilvania [Historical dictionary of localities in Transylvania], Editura Academiei Republicii Socialiste România, vol. II.

Ștef, D. (2016). Dicționar etimologic al localităților din județul Maramureș [Etymological dictionary of the localities in Maramureș county], Editura Ethnologica, Baia Mare.

TTRT-Sălaj = Tezaurul Toponimic al României. Transilvania: judeţul Sălaj [Toponymic Thesaurus of Romania. Transylvania: Sălaj county], Institutul de Lingvistică și Istorie Literară „Sextil Pușcariu”, Editura Academiei Române, Cluj-Napoca București, 2006. 
TTRT-Valea Hășdății = Loșonți, D. \& Vlad, S. (2006). Tezaurul Toponimic al României. Transilvania. Valea Hăşdăţii [Toponymic Thesaurus of Romania. Transylvania: Valea Hășdății], Editura Academiei Române, București.

TTRT-Valea Ierii = Loșonți, D. \& Vlad, S. (2010). Tezaurul Toponimic al României. Transilvania. Valea Ierii [Toponymic Thesaurus of Romania. Transylvania: Valea Ierii], Editura Academiei Române, București.

Vişovan, Ș. (2005). Monografia toponimică a Văii Izei [Toponymic monography of Valea Izei], Editura Mega, Editura Argonaut, Cluj-Napoca.

Vișovan, Ș. (2008). Toponimia Țării Lăpuşului [Toponymy of Țara Lăpuşului], Editura Universității de Nord, Baia Mare.

Xenopol, A. D. (1985). Istoria românilor [History of Romanians], $4^{\text {th }}$ edition, Editura Științifică și Enciclopedică, București.

\section{Appendix A. Abbreviations}

$$
\begin{aligned}
& \text { byn. - byname } \\
& \text { coll. - collective } \\
& \text { dim. - diminutive } \\
& \text { Hung. - Hungarian } \\
& \text { hyp - hypocoristic } \\
& \text { n.n. - nickname }
\end{aligned}
$$

p.n. - person name
prep. - preposition
Sl. - Slavic
suff. - suffix
top. - toponym
top. n. - topic name$$
\text { suff. - suffix }
$$ 